\title{
Determinants of satisfaction and loyalty of e-banking users during the COVID-19 pandemic
}

\author{
Arum Indrasari $^{a^{*}}$, Nurul Nadjmie ${ }^{a}$ and Endri Endri ${ }^{b}$
}

${ }^{a}$ Department of Accounting, Faculty of Economic and Business. Universitas Muhammadiyah Yogyakarta, Indonesia ${ }^{b}$ Universitas Mercu Buana, Jakarta, Indonesia

\section{H R O N I C L E}

Article history:

Received: July 22, 2021

Received in revised format: Sep-

tember 16, 2021

Accepted: December 8, 2021

Available online: December 8 , 2021

Keywords:

E-Banking

E-banking Service Quality (EBSQ)

E-Banking Satisfaction

E-Banking Loyalty

\section{A B S T R A C T}

This research aims to analyze factors affecting e-banking user satisfaction and e-banking user loyalty during Covid-19 pandemic with e-banking service quality that consists of reliability, privacy and security, design on application or website, and customer service and assistance as the independent variables, while the dependent variables in this study are e-banking user satisfaction and e-banking user loyalty. This research was viewed based on an e-banking user perspective. This research used nonprobability sampling and purposive sampling. This research is a quantitative study using primary data based on a questionnaire distributed online to 110 e-banking users like respondents. The hypothesis testing in this study used the SPSS analysis tool through the IBM SPSS Statistics Version 22 application. The result illustrates that e-banking service quality, reliability, and design on application and website influence both e-banking user satisfaction and e-banking user loyalty. Meanwhile, privacy and security only influence e-banking user loyalty, not on e-banking user satisfaction. Furthermore, customer service and assistance have no effect on both e-banking user satisfaction and ebanking user loyalty during the Covid-19 pandemic.

\section{Introduction}

The spread of the Corona Virus Disease-2019 (COVID-19) has a major impact on various aspects of life. COVID-19 spreads globally which infects many people and causes health problems and death (Nurhayati et al., 2021). COVID-19 has also caused the world economy to slump and a recession, including Indonesia (Endri et al., 2021). The symptoms of people with COVID19, in general, are fever and dry cough. Aches and pains, nasal congestion, conjunctivitis, headache, diarrhea, sore throat, loss of taste or scent, skin rash, and discoloration of fingers or toes are some of the other symptoms that some patients may experience. The signs and symptoms are typically mild and occur over time. COVID-19 is a disease that has a high rate of transmission. Transmission of COVID-19 can occur if there is contact with other people who are infected with this virus. COVID-19 is transmitted by droplets from the nose or mouth that come out when a person with COVID-19 coughs, sneezes or speaks. COVID-19 may also be contracted by inhaling the splash of an infected individual or meeting surfaces contaminated by the splash. Press Secretary for handling COVID-19 on the website of the Indonesian Health Ministry if a person carrying COVID-19 does not wear a mask and is in close contact with a person who does not use a mask and is vulnerable, the possibility of transmission reaches $100 \%$, if the sick persons wear a mask, while the group vulnerable to not wearing masks, the potential for transmission reaches $70 \%$, sick people wear masks, while healthy people don't wear masks, the transmission rate is $5 \%$, and if both wear masks, the potential for transmission is 1.5\%. Based on COVID-19 National Economic Management and Recovery Committee, until February 12, 2021, there were 1,201,859 positive cases, 32,936 deaths cases, and $1,004,117$ recovered cases of COVID-19 in Indonesia.

* Corresponding author. Tel.: +628129204067

E-mail address: arum.indrasari@umy.ac.id (A. Indrasari) 
The government has implemented certain policies to reduce the spread of COVID-19 in Indonesia. Several policies made by the government, including Social Distancing, Work from Home, Flight Restrictions, Large-Scale Social Restrictions (PSBB), and Lockdown in several regions have stopped economic activity, with reduced demand and disrupted supply chains around the world and affecting various sectors such as the aviation, tourism, investment, and trade. In the aviation market, Indonesia's flight restrictions to combat COVID-19 prompted several airlines to cancel flights, while others were forced to continue operating even though most of their airplane seats were vacant because of the increasingly widespread Coronavirus, many customers are delaying their vacation plans. The tourism industry is also impacted by the flight ban.

According to data from the Central Statistics Agency (BPS), In Indonesia, there were 2.07 million Chinese tourists in 2019, which is 12.8 percent of all foreign tourists in that year. The COVID-19 pandemic will continuously influence tourism support sectors such as hotels, restaurants, and retail entrepreneurs. If the number of visiting tourists decreases, turnover in trade, micro, small, and medium enterprises (SMEs) will also decrease. The business model will change over the transition period caused by the pandemic COVID-19. Producers, consumers, and distributors need to adapt to existing conditions. They are required to identify how to deliver their products and services with minimal and safe physical contact or seek digital substitutes (Seetharaman, 2020).

Rapid advances in technology are found in the era of industry 4.0, almost all companies use technology to process data and information for efficient and effective decision making in the business process. They also use technology in a competitive environment to provide services to consumers. Banking is one of the industries that competitively use technology for competition in consumer services (Tamaruddin et al., 2021). The use of information and communication technology in banking is relatively advanced, one type of technology that can be found in the banking industry is e-banking which can be in the forms of Automated Teller Machines (ATMs), Electronic Wallets (e-wallets), debit cards with chips, EDC machines, Mobile Banking, and Internet Banking. Therefore, face-to-face interaction as a process of consumption activities for customers and banking employees is replaced by customer interactions with technology. Technology also improves the efficiency and effectiveness of banking services. The patterns of consumer behavior also change over time with the increasing use of technology in banking services (Najib et al., 2021). In 2012, Indonesia had 13.6 million e-banking users and increased to 50.4 million users in 2016. The increasing number of users also increased the frequency of e-banking transactions, there were 150.8 million transactions in 2012, the increase of $169 \%$ in 2016 made the total transaction to become 405.4 million transactions. Technology complements human needs, it makes everything more practical and easier to do, so that human work that was previously difficult to do can be realized more easily, quickly, effectively, and efficiently.

During the COVID-19 pandemic, in the banking industry, digital use is becoming increasingly common among customers, the risk of virus transmission and distribution consequences caused by the transfer of cash could be a reason for the banking industry to direct their customers to become e-banking users. The most important things that need to be held in an electronic environment are trust and loyalty (Amir \& Chaudhry, 2019). During a pandemic, the use of technology like e-banking can increase dramatically because it is intended not only for more practical use for customers but also as retention in the spread of the coronavirus. The situation posed a challenge to the banking industry, especially in developing countries, and the importance of knowledge management in commercial banks grew as a result (Endri et al., 2020). COVID-19 prevention regulations by the Indonesian government also affect banking offices. Limitation on the number of customers who are allowed in the building and service hours is shorter than usual, even some banking offices are closed because positive cases of corona are found affect the needs of customers who are still oriented towards traditional banking. E-banking provides a variety of services and facilities that can lessen face-to-face activities to reduce the spread of COVID-19 for examples transfers, checking account balances and mutations, changing PINs, paying for electricity, water, or telephone, top-up e-money (OVO, Go-Pay, Dana, Shopee Pay, and others). This makes it easier for customers to make transactions in their daily lives, customers can make transactions that are needed anywhere, anytime without being limited by time. On account holders from three domestic banks in Pakistan which examines empirically study during the COVID-19 pandemic on e-banking service quality (ESBQ) and its impact on e-banking loyalty which is mediated by e-banking satisfaction (U1 Haq \& Awan, 2020) This study was conducted to find and understand the effect of E-banking service quality (EBSQ) factors towards E-Banking user satisfaction and loyalty during COVID-19 pandemic by taking E-banking users in Indonesia as subjects.

There are many types of E-Banking facilities provided by banking services, as mentioned above there are Automated Teller Machines (ATMs), Electronic Wallets (e-wallets), debit cards with chips, EDC machines, Mobile Banking, and Internet Banking. Therefore, in this study, the types of e-banking users who will become the research subjects will be limited. E-banking users who will become the research subjects are Mobile Banking and Internet Banking users only. The variables used as in the factors affecting e-banking user satisfaction and loyalty in this study are e-banking service quality (ESBQ) consists of reliability, privacy, and security, design of websites and applications, as well as customer service and assistance which will become independent variable in the study while the independent variable is E-Banking user satisfaction and E-Banking user loyalty. The subject of this research will be mobile banking and internet banking users of Indonesian local banks such as BCA, Mandiri, BNI, BRI, Permata, BSI, etc. 


\section{Literature Review and Hypotheses Development}

\subsection{Cognitive-motivational-relational theory}

The cognitive-motivational-relational theory states that emotions are related to judgments that affect the perceived changes in an individual's relationship with his environment and an individual's ability to achieve goals (Conroy et al., 2001). CMR theory can be used to link the mechanism of individual response aspects to service quality (Brady \& Robertson, 2001; Sivapalan \& Jebarajakirthy, 2017; Shankar \& Jebarajakirthy, 2019). During the COVID-19 pandemic, individuals feel changes in their environment, this causes certain aspects to be considered in decision making. In this study, certain aspects referred to are aspects of the quality of e-banking services which theoretically can affect consumer loyalty. CMR is a source of literature that supports the research framework on the influence of EBSQ on loyalty during the COVID-19 pandemic (U1 Haq \& Awan, 2020). This theory can also assist banks in making strategic management decisions in providing services to deal with COVID19 and digitalization. The form of Cognitive-motivational-relational theory in this study can be seen from the point of view of e-banking users in making transaction decisions, satisfaction, and loyalty in using e-banking during the COVID-19 pandemic. The decision to use e-banking is related to the assessment that affects the perceived changes in the individual's relationship with his environment and the individual's ability to achieve goals.

\subsection{Technology Acceptance Model (TAM)}

The Technology Acceptance Model (TAM) is adapted from the Theory of Reasoned Action (TRA) model, which can be defined as a reasoned theory of action with the premise that a person's reactions and perceptions of something will determine the person's attitude and behavior but explain and predict one's acceptance of information technology (Ajzen \& Fishbein 1975). Technology Acceptance Model (TAM) is used in Information Systems research as well, this is to explain the acceptance of a broad spectrum of new technologies such as technology operating systems to desktop application to online service (Rick et al., 2015). The purpose of this model is to explain the factors that cause users to accept technology. In this study, the decision of e-banking users to accept e-banking is seen from the perspective of satisfaction of e-banking service quality (EBSQ) Reliability, Privacy and Security, Design of website and application, Customer service, and assistance.

\subsection{The Effect of E-Banking Service Reliability on E-Banking User Satisfaction}

Reliability has become an important dimension to consider when evaluating service quality (Mansur et al., 2022; Widiyanto et al., 2021; Ayo et al., 2016). Customer satisfaction would be achieved if the e-banking service provider offers the best on what customers need efficiently in terms of services offered (Casalo et al., 2008). According to an empirical review of consumer perceptions of service quality in US banks, higher EBSQ quality contributes to user satisfaction (Foroughi et al., 2019). Many activities are conducted online due to the covid-19 pandemic. People must be able to adapt to the changing environment. The online customer expects more options available to them when paying, buying, or searching for goods online (Tan et al., 2003; Yang, 2003). In the e-banking case, website attributes offered play an important role in increasing customer satisfaction (Amin, 2016; Roy \& Headley, 2012). Consumers expect that the service offered by the service provider can be reliable in filing their needs. The usability of a website has a positive impact on consumer satisfaction (Casaló et al., 2008). Reliability is a core service scale to measure the quality of e-banking services (Zeithaml et al., 2002). Currently, there are many kinds of services offered by e-banking such as transferring online, paying a bill online, checking balance, and mutation information. These services offered are expected to fulfill customer needs moreover during COVID-19. If the services offered are reliable, it is assumed e-banking has good service quality where it can increase customer satisfaction in using e-banking.

\section{$\mathbf{H}_{1}$ : E-banking Service Reliability has a positive impact on E-banking Satisfaction.}

\subsection{The Effect of e-Banking Service in Privacy and Security on the e-banking Satisfaction}

Privacy and Security are important dimensions to consider when evaluating service quality (Hussien \& Abd El Aziz, 2013; Amin, 2016; Ayo et al., 2016; Pahala et al., 2021; Ricardianto et al., 2022). Research by Ganguli and Roy (2010) stated that service quality is a strong basis as a measure of customer satisfaction. According to an empirical review of consumer perceptions of service quality in US banks, higher EBSQ quality contributes to user satisfaction (Foroughi et al., 2019). Individual response mechanisms can be linked to service quality using CMR theory (Brady et al., 2001; Sivapalan \& Jebarajakirthy, 2017; Shankar \& Jebarajakirthy, 2019). Security and privacy are two important aspects of accepting e-banking as a development of technology. Customers are hesitant to provide personal information to websites for fear of it being taken advantage of via the internet, especially for financial transactions (Sathye, 1999; Aladwani, 2006; Black \& Lynch, 2001). Customers may have doubts about trusting the e-banking privacy policy (Gerrard \& Cunningham, 2003). From this, it can be concluded that privacy and security are dimensions that need to be considered by e-banking service providers. Research by Loonam and O’Loughlin (2008) entitled "Exploring e-service quality: a study of Irish online banking" finds that dimensions such as web usability, trust, access, and information quality service recovery, and flexibility have become important aspects of e-banking service provision. Good quality service in these dimensions will provide customer satisfaction and trust to service providers. E-banking services should be used with caution to ensure a high degree of Information security, confidentiality, and transaction protection are all important considerations (Le Brun et al., 2014; Wang et al., 2015). 


\subsection{The effect of Design of Website and Application and e-Banking Satisfaction}

Design on website and application is an important dimension to consider when evaluating service quality (Jun \& Cai, 2001; Jayawardhena, 2004; Ho \& Lin, 2010; Hussien \& Abd El Aziz, 2013; Amin, 2016; Ayo et al., 2016). To figure out what their online customers want, the first thing to do is to offer the best on what the customer needs efficiently in terms of services offered, design of the website (Casalo et al., 2008). Customer satisfaction would be achieved if the e-banking provider offers the best on what customers need efficiently in terms of the design of the website (Casalo et al., 2008). Content in e-banking websites or applications is one of the factors that influence e-banking acceptance. Internet users will enjoy using technology with displays and content of good quality that are easy to use and can create a flow experience when using the website (Loonam \& O'Loughlin, 2008). The design of a website and application is a technical characteristic in constituting core services (van Riel et al., 2001; Yang, 2005). It helps in lowering the perceived risk associated with using a financial portal platform (Zeithaml et al., 2002; Gounaris \& Dimitriadis, 2003). The design of a website and application as e-banking service quality (EBSQ) to calculate e-banking customer satisfaction can be seen in the design of a service provider's website and application that makes it easy for users to use the service.

\section{H3: Design of Website and Application in E-banking Services positively influence E-banking Satisfaction.}

\subsection{The Effect of Customer Service and Assistance to the e-Banking Satisfaction}

Customer support and assistance have become important dimensions to consider when evaluating service quality (Jun \& Cai, 2001; Jayawardhena, 2004; Ho \& Lin, 2010; Hussien \& Abd El Aziz, 2013; Amin, 2016; Ayo et al., 2016). CMR theory can be used to link the mechanism of individual response aspects to service quality (Brady et al., 2001; Sivapalan \& Jebarajakirthy, 2017; Shankar \& Jebarajakirthy, 2019). Customer satisfaction would be achieved if the customer's service quality standards were met. As a result, banks should try to figure out what their online customers want. ESBQ has a positive but not significant effect on e-banking customer satisfaction in Surabaya. Bauer et al. (2002) stated that customer service and assistance also become aspects of the portal's assessment from the customer's point of view. Customer service and assistance become ebanking service quality (EBSQ) dimensions that influence e-banking user satisfaction (Yaqin \& Ilfitriah, 2014). E-banking service quality (EBSQ) is divided into three dimensions: core services, additional services, and problem-solving services (Bauer et al.,2005). Since e-banking users' satisfaction varies depending on the technicality of the service, support services provided during e-banking should be less technical (Black \& Lynch, 2011). E-banking users also demand access to advice and help conventionally when they find a problem when conducting e-banking. Thus, customer service and assistance need to be easy to understand, simple and beneficial to achieving higher levels of satisfaction (Shankar \& Jebarajakirthy, 2019).

\section{$\mathbf{H}_{4}$ : Customer service and Assistance in E-banking services positively influence E-banking Satisfaction.}

\subsection{The Effect of Reliability to the e-Banking Loyalty}

Reliability is the first dimension of e-banking service quality (EBSQ). According to Gera (2011), if customers receive active, high-quality services from an e-banking website, they will return to use the platform for banking services and recommend it to others. Customers' loyalty to service providers may be influenced by reliability in the sense of quality service (Loonam \& O'Loughlin, 2008). Error-free operation and consistency in providing promised service are what reliability expects from a service provider (Saccani et al., 2014). Timely transaction processing and an accurate billing system are two of e-key banking's success factors in attracting customers to stay with this platform (Liang \& Pei-Ching, 2015; Shankar \& Kumari, 2016). The website and application in E-Banking Service Quality (EBSQ) is reliability and design have a positive impact on increasing e-banking loyalty, particularly during COVID-19, CMR is a source of literature that supports the research framework (U1 Haq \& Awan, 2020). Research by Shankar and Datta (2018) with the title of "The influence of e-banking service quality (EBSQ) on customer loyalty: A moderated mediation approach" indicates that ESBQ dimension reliability has a positive effect in enhanced customer loyalty to e-banking. Reliability is one of the main dimensions in EBSQ (Ho \& Lin, 2010; Hussien \& Abd El Aziz, 2013; Amin, 2016; Ayo et al., 2016). Based on the above description from previous studies, it can be concluded that consumer loyalty is influenced by efficiency when using e-banking.

\section{Hs: E-banking service Reliability has a positive impact on E-banking Loyalty.}

\subsection{The Effect of Privacy and Security on the e-Banking Loyalty}

According to Gera (2011), if customers receive active, high-quality services from an e-banking website, they will return to use the platform for banking services and recommend it to others, this explains the acceptance of a broad spectrum of new technologies such as technology operating systems to desktop application to online service. Privacy and security are the main dimensions of EBSQ (Ho \& Lin, 2010; Hussien \& Abd El Aziz, 2013; Amin, 2016; Ayo et al., 2016). ESBQ has a positive and significant effect on customer loyalty (Yaqin \& Ilfitriah, 2014). Privacy and security show the degree to which e-banking users are confident to share personal information on the e-banking platform provided by service providers. If privacy and 
security are well guaranteed by service providers, e-banking users will tend to trust them and show their loyalty (Thaichon et al., 2014; Shankar \& Kumari, 2016). Banks tend to use encryption technology: a combination of different unique identifiers such as password, mother's maiden name, a memorable date, or a few minutes of inactivity automatically logs users off the account to protect information privacy. Research by Shankar and Daffa (2018) with the title of "The influence of e-banking service quality (EBSQ) on customer loyalty: A moderated mediation approach" indicates that EBSQ dimensions of privacy and protection have effects on customer loyalty. Higher loyalty would benefit from properly protected privacy and protection in compliance with the code of ethics (Orel \& Kara, 2014; Thaichon et al., 2014). This allows the hypothesis to be raised.

\section{H6: E-banking Loyalty is positively influenced by Privacy and Security in the services.}

\subsection{The Effect of Design of Website and Application to the e-Banking Loyalty}

Website and Application are the third dimensions of EBSQ. Design of website and application is one of the main dimensions in EBSQ to measure e-banking user loyalty (Ho \& Lin, 2010; Hussien \& Abd El Aziz, 2013; Amin, 2016; Ayo et al., 2016). The e-banking service quality (EBSQ) and e-banking user loyalty have a connection. When it comes to e-banking loyalty, banks must manage their relationships with customers (Amin, 2016). CMR theory is used to link the influence of EBSQ on loyalty during the COVID-19 pandemic (U1 Haq \& Awan, 2020). Website designs were deemed essential to e-banking. It helps site navigation. The design of a website and application can be in the form of display, graphics, or color that portray bank image. The E-banking service provider needs to provide a website that can be easily understood, make it easier for users to use it and provide clear information on services offered to help the user deal with change due to COVID-19 and digitalization. Customer trustworthiness in e-commerce sites would be enhanced by the improved website and application design, as it has inspired them to become loyal to online service providers (Li \& Yeh, 2010). Research by Shankar and Daffa (2018) with the title of "The influence of e-banking service quality (EBSQ) on customer loyalty: A moderated mediation approach" indicates that the design of the website and application do not affect customer loyalty. However, this study is different from a study conducted by Li and Yeh (2010) that stated website and application design encourages e-banking customers to use their services more often. The hypothesis derived from the preceding clarification is:

\section{H7: Design of Website and Application in E-banking services positively influence E-banking Loyalty.}

\subsection{The Effect of Customer Service and Assistance to the e-Banking Loyalty}

Customer service and assistance are one of the main dimensions of EBSQ (Amin, 2016; Ayo et al., 2016). According to Gera (2011), customers will return to an e-banking website for banking services and promote it to others if they obtain active highquality services. Banks need to gain customer loyalty through their product features and services excellence. Banks need to maintain their relationships with customers when it comes to e-banking loyalty (Amin, 2016). Individual response mechanisms can be linked to service quality using CMR theory (Shankar \& Jebarajakirthy, 2019). Customer service and assistance are indicators of e-banking service quality (EBSQ), which is determined by how quickly a customer's issue is resolved during or after the service experience. In India and Pakistan, the support given by banking professionals is safer and more assured in facing any trouble (U1 Haq \& Awan, 2020). Sometimes e-banking users face problems during the update of the e-banking, while the quicker and more effective solution provided on time to users will result in higher satisfaction that led to loyalty in e-banking (Shankar \& Jebarajakirthy, 2019). Customers are more likely to trust a service if the online customer service support team responds quickly to customer queries, it effectively demonstrates a simple and painless recovery policy (Blut et al., 2015; Vahdat et al., 2021). As a result, these customers will stay loyal to them and spread the good news about their services. Research by Shankar and Datta (2018) with the title of "The influence of e-banking service quality (EBSQ) on customer loyalty: A moderated mediation approach" indicates that EBSQ dimensions of reliability, privacy and protection, and customer service and assistance have effects on customer loyalty. Following is a hypothesis based on the explanation:

Hs: Customer Service and Assistance in E-banking services positively influence E-banking Loyalty.

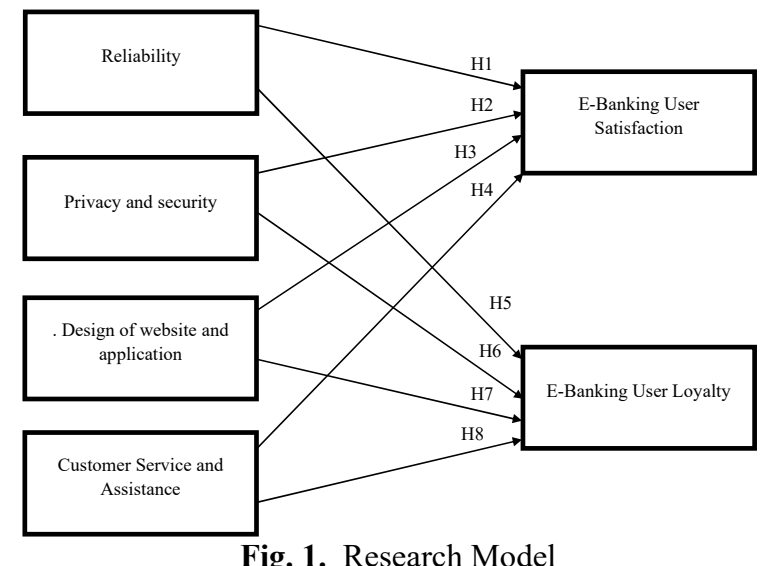

Fig. 1. Research Model 


\section{Research Method}

The subject for this research was e-banking users during the COVID-19 pandemic in Indonesia, e-banking mentioned can be internet banking or mobile banking. There are three main objects of this research, namely e-banking user satisfaction, ebanking user loyalty, and e-banking service quality (EBSQ) that are divided into four dimensions; reliability, privacy and security, design of website and application, and customer service and assistance. In this study, the sampling criteria were that the population taken as a sample had to use e-banking during the COVID-19 pandemic and must be Indonesian. This study used a questionnaire as a data collection technique. This study has two kinds of variables, they are dependent variables and independent variables. The dependent variable is a variable that is influenced by another variable, it becomes an output variable in the research. An Independent variable is a variable that influences the dependent variable, the change in variable dependent is caused by the independent variable. There are two dependent variables in this research, they are e-banking user satisfaction and e-banking user loyalty. E-banking service quality (EBSQ) with four dimensions in it (reliability, privacy and security, design of website and application, and customer service and assistance) are the independent variables. Measurement of the responses used a 5-point Likert Scale ranging from strongly disagree (1) to strongly agree (5).

\section{Results}

This study uses primary data collected using questionnaires. The questionnaire can be filled out if the respondent meets the criteria that have been set for this research, the criteria are that the respondent is an Indonesian citizen and is a user of ebanking services. The e-banking referred to in the research can be in the form of mobile banking (m-banking) or internet banking (I-Banking) users. Table 1 shows the statistical results on the 6 variables used in the study. N Valid refers to the number of respondents from the research, from the table above it can be concluded that there are 110 respondents in this study. The mean in the table means the average value based on respondents' answers in the questionnaire. Median shows the middle value, the value that separates the higher half from the lower half of the data. Mode is the value whose value occurs most frequently. Standard deviation means the difference between the mean and the value of each respondent. Minimum means the minimum value chosen by respondents in the questions with a range of 1-5 while the maximum is the maximum value. The sum in the table is the amount obtained from the data.

Table 1

Statistics Descriptive

\begin{tabular}{|c|c|c|c|c|c|c|}
\hline & Reliability & $\begin{array}{l}\text { Privacy and } \\
\text { Security }\end{array}$ & $\begin{array}{c}\text { Design of } \\
\text { Website and } \\
\text { Application }\end{array}$ & $\begin{array}{l}\text { Customer Service } \\
\text { and Assistance }\end{array}$ & $\begin{array}{c}\text { E-banking User } \\
\text { Satisfaction }\end{array}$ & $\begin{array}{c}\text { E-banking User } \\
\text { Loyalty }\end{array}$ \\
\hline $\mathrm{N}$ & 110 & 110 & 110 & 110 & 110 & 110 \\
\hline Mean & 18.34 & 13.47 & 16.90 & 20.45 & 22.76 & 17.93 \\
\hline Median & 19.00 & 14.50 & 17.00 & 21.00 & 24.00 & 19.00 \\
\hline Mode & 20 & 15 & 20 & 25 & 25 & 20 \\
\hline Std. Deviation & 2.100 & 1.957 & 2.483 & 3.383 & 3.017 & 2.633 \\
\hline Minimum & 8 & 3 & 10 & 12 & 8 & 5 \\
\hline Maximum & 20 & 15 & 20 & 25 & 25 & 20 \\
\hline Sum & 2017 & 1482 & 1859 & 2250 & 2504 & 1972 \\
\hline
\end{tabular}

The table above shows the value of the mean, median, mode, standard deviation, minimum, maximum, and sum for each variable. The first variable is the reliability variable, the mean value for the reliability variable is 18.34 , the median value is 19.00 , the mode value is 20 , the standard deviation is 2.100 . It also indicates that the minimum value is 8 and the maximum value is 20 , chosen by respondents in 4 questions of reliability variable with range 1-5. The sum of the reliability variable is 2017. The second variable is privacy and security. The mean value or average value chosen by respondents of privacy and security is 13.47 , the median value is 14.50 , the mode value is 15 , and the standard deviation is 1.957 . The minimum and maximum values for privacy and security are based on the results of respondents from 3 questions that have been given with a range of $1-5$ on each question, the minimum value is 3 and the maximum value is 15 . The sum for the privacy and security variable is 1482 .

The third is the design of the website and application variable. The mean value for the design of the website and application is 16.90 , the median is 17.00 , the model is 20 , the standard deviation is 2.483 , the minimum value is 10 , and the maximum value is 20 . The minimum and maximum values for the design of the website and application are based on the results of respondents from 4 questions that have been given with a range of 1-5 on each question. The value of the sum for the design of the website and application is 1859. The fourth variable is customer service and assistance. The mean value in customer service and assistance is 20.45 , the median is 21 , the model is 25 , the standard deviation is 3.383 , the minimum value is 12 , and the maximum value is 25 . The minimum and maximum value for customer service and assistance are based on the results of respondents from 5 questions that have been given with a range of 1-5 on each question. The value of customer service and assistance is 2250 .

The fifth variable is e-banking user satisfaction. The mean value for e-banking user satisfaction is 22.76 , the median is 24 , the model is 25 , the standard deviation is 3.017 , the minimum value is 8 , and the maximum value is 25 . The minimum and maximum values for e-banking user satisfaction are based on the results of respondents from 5 questions that have been given with a range of 1-5 on each question. The sum for this variable is 2504 . Last is the e-banking user loyalty variable, the mean 
value for the e-banking user loyalty variable is 17.93 , the median value is 19 , the mode value is 20 , the standard deviation is 2.633. It also indicates that the minimum value is 5 and the maximum value is 20 , chosen by respondents in 4 questions of reliability variable with range 1-5. The sum of the e-banking user loyalty variable is 1972 .

Table 2

The results of regression analysis

\begin{tabular}{|c|c|c|c|c|c|}
\hline & \multicolumn{2}{|c|}{ Unstandardized Coefficients } & Standardized Coefficients & $\mathrm{t}$ & Sig. \\
\hline Variable & $\mathrm{B}$ & Std. Error & Beta & & \\
\hline Reliability & 0.821 & 0.124 & 0.571 & 6.647 & 0.00 \\
\hline Privacy and Security & 0.14 & 0.135 & 0.091 & 1.042 & 0.30 \\
\hline Design of Website and Application & 0.367 & 0.1 & 0.302 & 3.684 & 0.00 \\
\hline Customer Service and Assistance & -0.065 & 0.069 & -0.073 & -0.946 & 0.35 \\
\hline
\end{tabular}

The results of the data analysis in table 8 above show that the reliability variable has a positive $B$ value of 0.821 with a $t$ value of 6.647 and a sig value of 0.000 . The value of $\operatorname{sig}<0.05$ and the value of $B$ are positive, based on these results it can be concluded that the reliability variable (X1) has a positive and significant effect on e-banking user satisfaction (Y1). The privacy and security variables have a positive B value of 0.140 with a t value of 1.042 and a sig value of 0.300 . The value of sig $>0.05$ and the value of $B$ are positive, based on these results it can be concluded that the privacy and security variable (X2) have a positive and not significant effect on e-banking user satisfaction (Y1). Website and application variables have a positive $B$ value of 0.367 with a $t$ value of 3.684 and a sig value of 0.000 . The value of sig $<0.05$ and the value of $B$ are positive, based on these results it can be concluded that the design of the website and application variable (X3) has a positive and significant effect on e-banking user satisfaction (Y1). The customer service and assistance variable have a negative B value of -0.065 with a $t$ value of -0.946 and a sig value of 0.346 . The value of $\operatorname{sig}>0.05$ and the value of $B$ are negative. Based on these results it can be concluded that the customer service and assistance variable (X4) has a negative and not significant effect on e-banking user satisfaction (Y1).

Table 3

The results of regression analysis

\begin{tabular}{|c|c|c|c|c|c|}
\hline & \multicolumn{2}{|c|}{ Unstandardized Coefficients } & Standardized Coefficients & $\mathrm{t}$ & Sig. \\
\hline Variable Independent & $\mathrm{B}$ & Std. Error & Beta & & \\
\hline Reliability & 0.37 & 0.12 & 0.294 & 3.02 & 0.003 \\
\hline Privacy and Security & 0.40 & 0.13 & 0.297 & 3.005 & 0.300 \\
\hline Design of Website and Application & 0.30 & 0.10 & 0.282 & 3.035 & 0.000 \\
\hline Customer Service and Assistance & -0.02 & 0.07 & -0.02 & -0.23 & 0.346 \\
\hline
\end{tabular}

The results of the data analysis in Table 3 above show that the reliability variable has a positive $\mathrm{B}$ value of 0.369 with a $\mathrm{t}$ value of 3.020 and a sig value of 0.003 . The value of $\operatorname{sig}<0.05$ and the value of $B$ are positive, based on these results it can be concluded that the reliability variable (X1) has a positive and significant effect on e-banking user loyalty (Y2). The privacy and security variable have a positive B value of 0.400 with a t value of 3.005 and a sig value of 0.003 . The value of sig $<0.05$ and the value of B are positive, based on these results it can be concluded that the privacy and security variable (X2) have a positive and significant effect on e-banking user loyalty (Y2). The design of the website and application variable has a positive $B$ value of 0.299 with a $t$ value of 3.035 and a sig value of 0.003 . The value of sig $<0.05$ and the value of $B$ are positive, based on these results it can be concluded that the design of the website and application variable (X3) has a positive and significant effect on e-banking user loyalty (Y2). Customer service and assistance variables have a negative B value of -0.016 with a $t$ value of -0.230 and a sig value of 0.818 . The value of $\operatorname{sig}>0.05$ and the value of $B$ are negative, based on these results it can be concluded that the customer service and assistance variable (X4) has a negative and not significant effect on e-banking user loyalty (Y2).

\section{Discussion}

The results of the data processing above show how the influence of reliability, privacy and security, design of website and application, and customer service and assistance as e-banking service quality (EBSQ) on e-banking user satisfaction and ebanking user loyalty is concluded from 110 respondents using e-banking services. E-banking service users consist of 95 mobile banking (M-Banking) users and 15 internet banking (I-Banking) users from different banks.

\subsection{E-banking Service Reliability has a positive impact on E-banking Satisfaction}

The first hypothesis in this study is that the reliability of e-banking services has a positive effect on e-banking satisfaction. Reliability is one form of e-banking service quality (EBSQ) which is the independent variable in this study. The results based on multiple regression analysis indicate that the significant value of the reliability variable on e-banking user satisfaction is 0.000 and the $B$ value is 0.821 . The significant value is smaller than the alpha value which is 0.05 and the positive $B$ value concludes that reliability has a significant positive effect on e-banking user satisfaction. Thus, the first hypothesis is accepted. This means that the better the reliability of e-banking services, the higher user satisfaction in using e-banking services during the COVID-19 pandemic. These findings are in line with a prior study (Amin, 2016; Roy \& Handley, 2012), which finds that 
consumers expect service providers to meet their needs reliably. In the case of e-banking, the available website or application attributes play an important role in increasing consumer satisfaction. Reliability plays a role in the ability of services provided by service providers to perform services as promised consistently and accurately (Parasuraman et al., 2005). Customers examine whether e-banking services can be relied on to assist satisfy their transaction demands by using e-banking services, particularly during the COVID-19 pandemic, which prohibited numerous activities. Accuracy in providing promised services and error-free services is one of the things that e-banking users expect (Saccani et al., 2014). If the services offered are reliable, it means e-banking has good service quality where it can increase customer satisfaction in using e-banking.

\subsection{E-banking Service in Privacy and Security has a positive impact on E-banking Satisfaction}

The second hypothesis in this study is that e-banking service in privacy and security has a positive impact on e-banking satisfaction. Privacy and security are one form of e-banking service quality (EBSQ) which is the independent variable in this study. Based on the results of the multiple regression analysis, the significant value of the privacy and security variable on ebanking user satisfaction is 0.300 and the $B$ value is 0.140 . The significant value is greater than the alpha value which is 0.05 and the positive B value concludes that privacy and security have a positive but not significant effect on e-banking user satisfaction. Thus, the second hypothesis is rejected. The insignificant result means that privacy and security do not affect user satisfaction in using e-banking services during the COVID-19 pandemic. This result is contrary to previous research (U1 Haq \& Awan, 2020) which states that privacy and security have a significant relationship with e-banking user satisfaction. However, this result proves Sheng and Liu (2010) findings that service quality has no significant relationship on e-banking user satisfaction with indices of accessibility and privacy. Privacy and security refer to the extent to which customers' trust in service providers in the personal information they share through platforms is protected and safe from tampering (Hussien \& Abd El Aziz, 2013). Services that are not carried out face-to-face due to the COVID-19 pandemic might raise doubts for customers to share their personal information. E-banking services with indicators of insecurity have no significant effect on e-banking user satisfaction (Ganguli \& Roy, 2010). According to the above explanation, services that are not carried out faceto-face due to the COVID-19 pandemic, where security is vulnerable in this situation, are not a factor in consumers' satisfaction with e-banking services.

\subsection{Design of Website and Application in E-banking Services positively influence E-banking Satisfaction}

The third hypothesis in this study is the design of websites and applications in e-banking services positively influence ebanking satisfaction. Design of website and application is one form of e-banking service quality (EBSQ) which is the independent variable in this study. Based on the results of the multiple regression analysis, the significant value of the design of website and application variable on e-banking user satisfaction is 0.000 and the B value is 0.369 . The value is significantly smaller than the alpha value which is 0.05 and the positive B value concludes that the design of the website and application has a significant positive effect on e-banking user satisfaction. Thus, the third hypothesis is accepted. This means that the better the design of the website and application in e-banking services, the higher user satisfaction in using e-banking services during the COVID-19 pandemic. The display, content, quality provided in e-banking applications or websites can create a flow experience when using the e-banking service. The results of the hypothesis above are consistent with research that shows that one of the most important elements in determining a website's quality is its design (Loiacono et al., 2000; Aladwani \& Palvia, 2002; Yang \& Fang, 2004; Yang, 2005). Consumers should be able to use e-banking with ease thanks to the design of the website and application. Customer satisfaction rises with an engaging e-banking website (Kim et al., 2009; Vera \& Trujillo, 2013; Amin, 2016). The different aspects contained in an e-banking website that consumers utilize to interact with the website, such as navigation, comprehensive information, and transaction processing, are referred to as website and application design (Wolfinbarger \& Gilly, 2003). The design of the website and application affects user satisfaction in using e-banking services. The better and easier to understand the design of the website and application on e-banking will increase the satisfaction of e-banking service users, especially during the COVID-19 pandemic because of the prohibition on some direct transactions.

\subsection{Customer service and Assistance in E-banking services positively influence E-banking Satisfaction}

The fourth hypothesis in this study is that customer service and assistance in e-banking services positively influence e-banking satisfaction. Customer service and assistance is one form of e-banking service quality (EBSQ) which is the independent variable in this study. Based on the results of the multiple regression analysis, the significant value of the customer service and assistance variable on e-banking user satisfaction is 0.346 and the $\mathrm{B}$ value is -0.065 . The significant value is greater than the alpha value which is 0.05 and the negative $B$ value concludes that the customer service and assistance do not have a significant effect on e-banking user satisfaction. Thus, the fourth hypothesis is rejected. The insignificant result means that customer service and assistance do not affect user satisfaction in using e-banking services during the COVID-19 pandemic. Customer Service and Assistance means how an e-banking provider helps customers to solve their problems and help consumers in their needs with fast and precise responses in solving their problems (Blut et al., 2016). The results of the hypothesis test above are contrary to research which states that customer satisfaction with electronic banking is influenced by design, speed, security, information content, and customer service ( $\mathrm{Li} \&$ Yeh, 2010). It was discovered that there is no substantial association between customer service and e-banking service satisfaction. Because their problems have not been fully handled, the indirect impact 
of customer service and assistance on e-banking satisfaction may be disregarded. However, the financial sector must pay great attention, especially during difficult times like the COVID-19 pandemic (U1 Haq \& Awan, 2020).

\subsection{E-banking service Reliability has a positive impact on E-banking Loyalty}

The fifth hypothesis in this study is that e-banking service reliability has a positive impact on e-banking loyalty. Reliability is one form of e-banking service quality (EBSQ) which is the independent variable in this study. Based on the results of the multiple regression analysis, the significant value of the reliability variable on e-banking user loyalty is 0.003 and the B value is 0.369 . The value is significantly smaller than the alpha value of 0.05 and the positive $\mathrm{B}$ value concludes that reliability has a significant effect on e-banking user loyalty. Thus, the fifth hypothesis is accepted. This means that the better the reliability of e-banking services, the higher user loyalty in using e-banking services during the COVID-19 pandemic. When deciding to use e-banking, customers must have hope that the services provided by e-banking can be relied on to help meet their transaction needs, especially during the COVID-19 pandemic which causes many activities to be limited. Reliability is the ability of service provided by service providers to perform services as promised consistently and accurately (Parasuraman et al., 2005). E-banking users pay attention to the reliability of e-banking services and have a significant effect on e-banking user loyalty. This result is in line with previous research (Blut, 2016; Saccani et al., 2014; Vahdat et al., 2021). Account-holders are satisfied with the reliability of the services and performance offered on e-banking which later became a source of loyalty during COVID-19 (U1 Haq \& Awan, 2020).

\subsection{E-banking Loyalty is positively influenced by Privacy and Security in the E-Banking Services}

The sixth hypothesis in this study is that e-banking loyalty is positively influenced by privacy and security in e-banking services. Privacy and security are one form of e-banking service quality (EBSQ) which is the independent variable in this study. Based on the results of the multiple regression analysis, the significant value of the reliability variable on e-banking user loyalty is 0.003 and the $\mathrm{B}$ value is 0.400 . The value is significantly smaller than the alpha value of 0.05 and the positive $B$ value concludes that privacy and security have a significant effect on e-banking user loyalty. Thus, the sixth hypothesis is accepted. This means that the better the privacy and security of e-banking services, the higher user loyalty in using e-banking services during the COVID-19 pandemic. During the COVID-19 pandemic, many transactions that previously could be done face-to-face have now become impossible. This is a consideration for respondents to continue to use e-banking. Consumers are more likely to trust online banking service providers who can guarantee personal data security and safe transactions (Thaichon et al., 2014; Shankar \& Kumari, 2016). Customers' security in service providers in the personal information they provide through platforms is secured and safe from interference, which is referred to as privacy and security (Hussien \& Abd El Aziz, 2013). This study shows that privacy and security have a significant effect on e-banking user loyalty during the COVID-19 pandemic, these results are in line with previous research. If privacy and security are well guaranteed by service providers, e-banking users will tend to trust them and show their loyalty (Thaichon et al., 2014; Shankar \& Kumari, 2016).

\subsection{Design of Website and Application in E-banking services positively influence E-banking Loyalty}

The seventh hypothesis in this study is that the design of websites and applications in e-banking services positively influences e-banking loyalty. Design of website and application are one form of e-banking service quality (EBSQ) which is the independent variable in this study. Based on the results of the multiple regression analysis, the significant value of the design of website and application variable on e-banking user loyalty is 0.003 and the B value is 0.299 . The value is significantly smaller than the alpha value of 0.05 and the positive $B$ value concludes that the design of the website and application have a significant effect on e-banking user loyalty. Thus, the seventh hypothesis is accepted. This means that the better the design of the website and application in e-banking services, the higher user loyalty in using e-banking services during the COVID-19 pandemic. This research shows that the variable design of website and application as one of EBSQ has a significant effect on e-banking user loyalty. These results are in line with previous research (Blut, 2016; Saccani et al., 2014; Vahdat et al., 2021). However, this result contrasts with the research of Shankar and Datta (2018) which found that the design of website and application didn't have significant effects on e-banking user loyalty. The difference in the results in each of these studies may be caused by the environment. Individuals experience changes in their surroundings during the COVID-19 pandemic, which necessitates the consideration of factors in decision-making. The use of e-banking is becoming increasingly common. E-banking consumers are more likely to use their services because of the websites and applications design (Li \& Yeh, 2010). Users' loyalty to ebanking services is influenced by the design of the website and application.

\subsection{Customer Service and Assistance in E-banking services positively influence E-banking Loyalty}

The eight hypotheses in this study are customer service and assistance in e-banking services positively influence e-banking loyalty. Customer service and assistance are one form of e-banking service quality (EBSQ) which is the independent variable in this study. Based on the results of the multiple regression analysis, the significant value of the customer service and assistance variable on e-banking user loyalty is 0.818 and the B value is -0.016 . The significant value is greater than the alpha value which is 0.05 and the negative $B$ value concludes that the customer service and assistance do not have a significant effect on e-banking user loyalty. Thus, the eight hypotheses are rejected. The insignificant result means that customer service 
and assistance do not affect user satisfaction in using e-banking services during the COVID-19 pandemic. Customer service and assistance have no significant effects on e-banking user loyalty (Shankar \& Datta, 2018). The results of these previous studies have the same results as this study. The findings reveal that during the COVID-19 pandemic, customer service and support in e-banking services do not affect e-banking service users' loyalty. Sometimes e-banking users face problems during the update of the e-banking, but these problems can be solved because the website and application design has elements to help site navigation. CMR theory is used to link the mechanism of individual response to decision making and service quality (Brady et al, 2001; Sivapalan \& Jebarajakirthy, 2017).

\section{Conclusion}

Based on the analysis of 110 questionnaires aimed at establishing the impact of e-banking service quality which includes reliability, privacy and security, website and application design, and customer service and assistance, on e-banking user satisfaction and e-banking user loyalty, the conclusion of the research is as follows; The reliability variable has a significant positive impact on e-banking user satisfaction in using e-banking services in Indonesia during the COVID-19 pandemic, privacy and security variable has no significant impact on e-banking user satisfaction in using e-banking services in Indonesia during the COVID-19 pandemic, design of website and application variable has a significant positive impact on e-banking user satisfaction in using e-banking services in Indonesia during the COVID-19 pandemic, customer service and assistance variable has no significant impact on e-banking user satisfaction in using e-banking services in Indonesia during the COVID19 pandemic, the reliability variable has a significant positive impact on e-banking user loyalty in using e-banking services in Indonesia during the COVID-19 pandemic, privacy and security variable has a significant positive impact on e-banking user loyalty in using e-banking services in Indonesia during the COVID-19 pandemic, design of website and application variable has a significant positive impact on e-banking user loyalty in using e-banking services in Indonesia during the COVID-19 pandemic, and customer service and assistance variable has no significant impact on e-banking user loyalty in using e-banking services in Indonesia during the COVID-19 pandemic.

This study is limited in its data-gathering using an online questionnaire, which has the flaw of having respondents who answer the questionnaire in a non-serious manner and cannot be regulated. The scope used in this research is not very specific. The research is conducted on e-banking users in Indonesia. Only two types of e-banking services are used in this study namely internet banking (I-Banking) and mobile banking (M-Banking). Further research can narrow the area of the study, allowing the study's findings to be more particular. Future research can add more types of e-banking services used in research so that the sample in the study is more varied and numerous. The next study is expected to be able to use a combined data-gathering strategy, which will include data from questionnaires and interviews. This research confirms that e-banking service quality, reliability, and design on application and website influence both e-banking user satisfaction and e-banking user loyalty. Meanwhile, privacy and security only influence e-banking user loyalty, not on e-banking user satisfaction. Furthermore, customer service and assistance have no effect on both e-banking user satisfaction and e-banking user loyalty during the Covid-19 pandemic. Thus, this research can be used by academics or banking employees as a source or additional reference in their field.

\section{References}

Ajzen, I., \& Fishbein, M. (1975). A Bayesian analysis of attribution processes. Psychological Bulletin, 82(2), $261-277$.

Aladwani, A. M., \& Palvia, P. C. (2002). Developing and validating an instrument for measuring user-perceived web quality. Information \& management, 39(6), 467-476.

Aladwani, A.M. (2006). An empirical test of the link between website quality and forward enterprise integration with web consumers. Business Process Management Journal, 12( 2), 178-190. https://doi.org/10.1108/14637150610657521

Amin, M. (2016). Internet banking service quality and its implication on e-customer satisfaction and e-customer loyalty. International Journal of Bank Marketing, 34(3), 280-306. https://doi.org/10.1108/IJBM-10-2014-0139

Amir, M., \& Chaudhry, N. I. (2019). Linking environmental strategy to firm performance: A sequential mediation model via environmental management accounting and top management commitment. Pakistan Journal of Commerce and Social Sciences (PJCSS), 13(4), 849-867.

Ayo, C. k., Oni, A. A., Adewoye, O. J., \& Eweoya, I. O. (2016). E-banking users' behavior: e-service quality, attitude, and customer satisfaction. International Journal of Bank Marketing, 34(3), 347-367. https://doi.org/10.1108/IJBM-12-20140175

Bauer, H. H., Hammerschmidt, M., \& Falk, T. (2005). Measuring the quality of e-banking portals. International Journal of Bank Marketing, 23(2), 153-175. https://doi.org/10.1108/02652320510584395

Black, S. E., \& Lynch, L. M. (2001). How to compete: the impact of workplace practices and information technology on productivity. Review of Economics and Statistics, 83(3), 434-445. DOI:10.1162/00346530152480081

Blut, M. (2016). E-service quality: development of a hierarchical model. Journal of Retailing, 92(4), 500-517.

Brady, M. K., Robertson, C. J., \& Cronin, J. J. (2001). Managing behavioral intentions in diverse cultural environments: An investigation of service quality, service value, and satisfaction for American and Ecuadorian fast-food customers. Journal of International Management, 7(2), 129-149.

Casaló, L. V., Flavián, C., \& Guinalíu, M. (2008). The role of satisfaction and website usability in developing customer loyalty 
and positive word-of-mouth in e-banking services. International Journal of Bank Marketing, 26(6), 399-417. https://doi.org/10.1108/02652320810902433

Conroy, D. E., Poczwardowski, A., \& Henschen, K. P. (2001). Evaluative criteria and consequences associated with failure and success for elite athletes and performing artists. Journal of applied sport psychology, 13(3), 300-322.

Endri, E., Aipama, W., Razak, A., Sari, L., \& Septiano, R. (2021). Stock price volatility during the COVID-19 pandemic: The GARCH model. Investment Management and Financial Innovations, 18(4), 12-20. doi:10.21511/imfi.18(4).2021.02

Endri, E., Marlina, A., \& Hurriyaturrohman (2020). Impact of internal and external factors on the net interest margin of banks in Indonesia. Banks and Bank Systems, 15(4), 99-107. doi:10.21511/bbs.15(4).2020.09

Foroughi, B., Iranmanesh, M., \& Hyun, S.S. (2019). Understanding the determinants of mobile banking continuance usage intention. Journal of Enterprise Information Management, 32(6), 1015-1033. https://doi.org/10.1108/JEIM-10-2018-0237

Ganguli, S., \& Roy, S.K. (2010). Service quality dimensions of hybrid services. Managing Service Quality: An International Journal, 20(5), 404-424. https://doi.org/10.1108/09604521011073713

Ganguly, B., Dash, S. B., Cyr, D., \& Head, M. (2010). The effects of website design on purchase intention in online shopping: the mediating role of trust and the moderating role of culture. International Journal of Electronic Business, 8(4-5), 302330.

Gera, R. (2011). Modeling the service antecedents of favorable and unfavorable behavior intentions in life insurance services in India: An SEM study. International Journal of Quality and Service Sciences, 3(2), 225242. https://doi.org/10.1108/17566691111146113

Gerrard, P., \& Cunningham, J.B. (2003). The diffusion of Internet banking among Singapore consumers. International Journal of Bank Marketing, 21(1), 16-28. https://doi.org/10.1108/02652320310457776

Gounaris, S. \& Dimitriadis, S. (2003). Assessing service quality on the Web: evidence from business-to-consumer portals. Journal of Services Marketing, 17(5), 529-548. https://doi.org/10.1108/08876040310486302

Ho, C.B., \& Lin, W. (2010). Measuring the service quality of internet banking: scale development and validation. European Business Review, 22(1), 5-24. https://doi.org/10.1108/09555341011008981

Hussien, M. I., \& Abd El Aziz, R. (2013). Investigating e-banking service quality in one of Egypt's banks: a stakeholder analysis. The TQM Journal, 25(5), 557-576. https://doi.org/10.1108/TQM-11-2012-0086

Jayawardhena, C. (2004). Measurement of service quality in internet banking: the development of an instrument. Journal of marketing management, 20(1-2), 185-207.

Jun, M., \& Cai, S. (2001). The key determinants of Internet banking service quality: a content analysis. International Journal of Bank Marketing, 19(7), 276-291. https://doi.org/10.1108/02652320110409825

Kim, G., Shin, B., \& Lee, H. G. (2009). Understanding dynamics between initial trust and usage intentions of mobile banking. Information Systems Journal, 19(3), 283-311.

Le Brun, A. M., McCarthy, I. G., Schaye, J., \& Ponman, T. J. (2014). Towards a realistic population of simulated galaxy groups and clusters. Monthly Notices of the Royal Astronomical Society, 441(2), 1270-1290.

Li, Y. M., \& Yeh, Y. S. (2010). Increasing trust in mobile commerce through design aesthetics. Computers in Human Behavior, 26(4), 673-684.

Liang, C. C., \& Pei-Ching, W. (2015). Internet-banking customer analysis based on perceptions of service quality in Taiwan. Total Quality Management \& Business Excellence, 26(5-6), 550-568.

Loiacono, E. T. (2000). WebQual ${ }^{\mathrm{TM}}$ : A Web site quality instrument. The University of Georgia.

Loonam, M., \& O'Loughlin, D. (2008). Exploring e-service quality: A study of Irish online banking. Marketing Intelligence and Planning, 26(7), 759-780. https://doi.org/10.1108/02634500810916708

Mansur, S., Yuliawati, E., Saragih, N., Daniel, R., Susilo, A., \& Endri, E. (2022). Public perception on the quality of one-stop public service mall. Journal of Management Information and Decision Sciences, 25(S1), 1- 10.

Najib, M., Ermawati, W. J., Fahma, F., Endri, E., \& Suhartanto, D. (2021). FinTech in the Small Food Business and Its Relation with Open Innovation. Journal of Open Innovation: Technology, Market, and Complexity, 7(1), 88.

Nurhayati, I., Endri, E., Aminda, R.S., \& Muniroh, L. (2021). Impact of COVID-19 on Performance Evaluation Large Market Capitalization Stocks and Open Innovation. Journal of Open Innovation: Technology, Market, and Complexity, 7(1), 56. https://doi.org/10.3390/joitmc7010056

Orel, F. D., \& Kara, A. (2014). Supermarket self-checkout service quality, customer satisfaction, and loyalty: Empirical evidence from an emerging market. Journal of Retailing and Consumer Services, 21(2), 118-129.

Pahala, Y., Widodo, S., Kadarwati., Azhari, M., Muliyati., Lestari, N.I., Madjid, S.A., Sidjabat, S., Limakrisna, N., \& Endri, E. (2021). The effects of service operation engineering and green marketing on consumer buying interest. Uncertain Supply Chain Management, 9(3), 603-608. https://doi: 10.5267/j.uscm.2021.5.011

Parasuraman, A., Zeithaml, V. A., \& Malhotra, A. (2005). ES-QUAL: A multiple-item scale for assessing electronic service quality. Journal of service research, 7(3), 213-233.

Ricardianto, P., Wibowo, H., Agusinta, L., Abdurachman, E., Suryobuwono, A., Fachrial, P., Setiawan, A., Rafi, S., Maemunah, S \& Endri, E. (2022). Determinants of airport train operational performance. International Journal of Data and Network Science, 6(1), 91-98. doi: 10.5267/j.ijdns.2021.9.019

Riek, M., Bohme, R., \& Moore, T. (2015). Measuring the influence of perceived cybercrime risk on online service avoidance. IEEE Transactions on Dependable and Secure Computing, 13(2), 261-273.

Roy, H. E., \& L, Handley, L. J. (2012). Networking: a community approach to invaders and their parasites. Functional Ecology, 26(6), 1238-1248. 
Saccani, N., Visintin, F., \& Rapaccini, M. (2014). Investigating the linkages between service types and supplier relationships in serviced environments. International Journal of Production Economics, 149, 226-238.

Sathye, M. (1999). Adoption of Internet banking by Australian consumers: an empirical investigation. International Journal of Bank Marketing, 17(7), 324-334. https://doi.org/10.1108/02652329910305689

Seetharaman, P. (2020). Business models shifts: Impact of COVID-19. International Journal of Information Management, 54, 102173. https://doi.org/10.1016/j.ijinfomgt.2020.102173

Shankar, A., \& Datta, B. (2018). Factors Affecting Mobile Payment Adoption Intention: An Indian Perspective. Global Business Review, 19(35), 725-895. https://doi.org/10.1177/0972150918757870

Shankar, A., \& Jebarajakirthy, C. (2019). The influence of e-banking service quality on customer loyalty: A moderated mediation approach. International Journal of Bank Marketing, 37(5), 1119-1142. https://doi.org/10.1108/IJBM-03-20180063

Shankar, A., \& Kumari, P. (2016). Factors affecting mobile banking adoption behavior in India. Journal of Internet Banking and Commerce, 21(1), 1-24.

Sivapalan, A., \& Jebarajakirthy, C. (2017). An application of retailing service quality practices influencing customer loyalty toward retailers. Marketing Intelligence \& Planning, 35(7), 842-857. DOI:10.1108/MIP-09-2016-0178

Saluy, A.B., Abidin, Z., Djamil, M., Kemalasari, N., Hutabarat, L., Pramudena, S.M., \& Endri, E. (2021). Employee productivity evaluation with human capital management strategy: The case of covid-19 in Indonesia. Academy of Entrepreneurship Journal, 27(5), 1-9.

Sheng, T., \& Liu, C. (2010). An empirical study on the effect of e-service quality on online customer satisfaction and loyalty. Nankai Business Review International, 1(3), 273-283. https://doi.org/10.1108/20408741011069205

Ul Haq, I., \& Awan, T.M. (2020). Impact of e-banking service quality on e-loyalty in pandemic times through interplay of esatisfaction. Vilakshan - XIMB Journal of Management, 17 (1/2), 39-55. https://doi.org/10.1108/XJM-07-2020-0039

Vahdat, A., Alizadeh, A., Quach, S., \& Hamelin, N. (2021). Would you like to shop via mobile app technology? The technology acceptance model, social factors, and purchase intention. Australasian Marketing Journal, 29(2), 187-197.

van Riel, A.C.R., Liljander, V., \& Jurriëns, P. (2001). Exploring consumer evaluations of e-services: a portal site. International Journal of Service Industry Management, 12(4), 359-377. https://doi.org/10.1108/09564230110405280

Vera, J., \& Trujillo, A. (2013). Service quality dimensions and superior customer perceived value in retail banks: An empirical study on Mexican consumers. Journal of Retailing and Consumer Services, 20(6), 579-586.

Tamaruddin., Firdaus, A., \& Endri, E. (2020). Customer Satisfaction Mediates the Effect of Self Service Technology on Customer Loyalty in Islamic Bank E-Banking Services in Indonesia. ILTIZAM Journal of Shariah Economics Research, 4(2), 1-15. DOI: : https://doi.org/10.30631/iltizam.v4i2.596

Tan, J., Xi, N., \& Wang, Y. (2003). Integrated task planning and control for mobile manipulators. The International Journal of Robotics Research, 22(5), 337-354.

Thaichon, P., Lobo, A., Prentice, C., \& Quach, T. N. (2014). The development of service quality dimensions for internet service providers: retaining customers of different usage patterns. Journal of Retailing and Consumer Services, 21(6), 1047-1058.

Wang, D. H. M., Chen, P. H., Yu, T. H. K., \& Hsiao, C. Y. (2015). The effects of corporate social responsibility on brand equity and firm performance. Journal of business research, 68(11), 2232-2236.

Widiyanto, P., Jaya Sakti, R.F., Setiawan, E.B., Manfaluthy, M., Suryaningsih, L., Ricardianto, P., Kamar, K., \& Endri, E. (2021). The Relationship between Service Quality, Timeliness of Arrival, Departure Flip Ship Logistics and People and Customer Satisfaction: A Case in Indonesia. Academy of Entrepreneurship Journal, 27(6), 1-10.

Wolfinbarger, M., \& Gilly, M. C. (2003). email: dimensionalizing, measuring, and predicting retail quality. Journal of retailing, 79(3), 183-198.

Yang, Z., \& Fang, X. (2004). Online service quality dimensions and their relationships with satisfaction: A content analysis of customer reviews of securities brokerage services. International Journal of Service Industry Management, 15(3), 302326. https://doi.org/10.1108/09564230410540953

Yang, K. C. (2005). Exploring factors affecting the adoption of mobile commerce in Singapore. Telematics and informatics, 22(3), 257-277.

Yang, J., Kolari, J. W., \& Min, I. (2003). Stock market integration and financial crises: the case of Asia. Applied Financial Economics, 13(7), 477-486.

Yaqin, A., \& Ilfitriah, A. M. (2015). Pengaruh Kualitas Pelayanan Terhadap Kepuasan Dan Loyalitas Nasabah Bank Pengguna E-Banking Di Surabaya. Journal of Business and Banking, 4(2), 245. https://doi.org/10.14414/jbb.v4i2.375

Zeithaml, V. A., Parasuraman, A., \& Malhotra, A. (2002). Service quality delivery through web sites: a critical review of extant knowledge. Journal of the academy of marketing science, 30(4), 362-375.

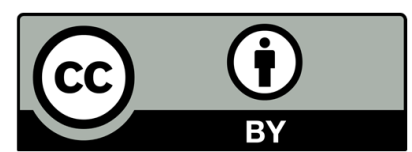

(C) 2022 by the authors; licensee Growing Science, Canada. This is an open access article distributed under the terms and conditions of the Creative Commons Attribution (CC-BY) license (http://creativecommons.org/licenses/by/4.0/). 